\title{
Vendinger mod følelser og affekt
}

\author{
Af Lene Bull Christiansen, \\ BoletTe Frydendahl \& \\ Christina Hee Pedersen
}

har længe været over akademia: Der er udgivet flere readers i affektteori (e.g. Gregg \& Seigworth 2010; Clough \& Halley 2007) og Feminist Theory, samt adskillige andre tidsskrifter indenfor forskellige discipliner, har haft temanumre dedikeret til affektteoretiske perspektiver (e.g. Pedwell \& Whitehead 2012; Blackman \& Featherstone 2010; Al-Samman \& El-Ariss 2013; Fritsch \& Markussen; La Caze \& Lloyd 2011).

Ofte fremhæves Eve K. Sedgwick og Adam Franks "Shame in the Cybernetic Fold” (Sedgwick \& Frank 1995) og Brian Massumis "The Autonomy of Affect" (Massumi 1995) som begyndelsen på det, der er blevet kaldt 'den affektive vending'. Siden disse tekster udkom, har vendingen mod affekt skabt debat i kønsforskningskredse og inspireret en lang række udgivelser, kurser og konferencetemaer både internationalt og i nordisk og skandinavisk kønsforskning. ${ }^{1}$ Kvinder, Køn \& Forskning 
fandt det derfor passende at udgive et temanummer, der kan give eksempler på, hvordan nordisk kønsforskning har ladet sig inspirere af vendingen mod affekt og følelse.

At følelser og affekt fylder meget i akademisk tænkning på tværs af fag netop nu er måske ikke så mærkeligt. Mere end nogensinde bliver vores forståelse af os selv som mennesker forklaret i psykologiske termer og knyttet til følelser. I akademia giver det sig bl.a. udtryk i, at psykologiens ordvalg og logikker flytter ind hos stadig flere fagtraditioner, som ikke før har talt i psykologiske termer. Samtidig bliver individualiserende psykologiske teorier i stadig højere grad legitime forklaringsmodeller på både samfundsmæssige og individuelle problemer: Såvel stress på arbejdspladsen som stereotype kønsarbejdsdelinger i familier synes at blive forklaret med personlighedstype og individuelle præferencer og følelser.

Den poststrukturalistiske feministiske forskning i Skandinavien har gennem mange år vist, hvordan individualisering og personliggørelse af samfundsmæssige problemer under neoliberalismen bliver en nedbrydende selvstyringstvang hos den enkelte. Når diskurser om personlighed, følelser og neuroner umærkeligt bliver hegemoniske, bliver denne type handlinger og andre alternative perspektiver samtidig svært tilgængelige. Jan de Vos spørger i sin bog, som handler om psykologiseringen i den globale tidsalder, om ikke psykologiens tilsyneladende kolonisering af nye fagområder også kan være udtryk for, at det bliver en samfundsmæssig nødvendighed at forholde sig til de psykiske kræfter, som mo-biliseres, $i$ den tid vi lever $i$, da de indebærer en betydelig politisk trussel (2012: 7). I tråd med de Vos, kunne vi således i forbindelse med dette temanummer kritisk spørge, om kønsforskningens vending mod affekt kan forstås som en del af samme tendens: 'Why this (re)turn to affect. Why now?' - som Melissa Autumn White spørger i sit review af tre bøger skrevet indenfor den affektteoretiske vending (White 2008).
Clare Hemmings' artikel "Invoking affect" (2005), der har tjent som referencepunkt for både tilhængere og kritikere af den affektive vending, kan læses som en advarsel mod, at affektperspektiver bliver del af en individualiseringstendens. Hemmings mener, at Sedgwicks og Massumis søgen efter affekter, der kan transformere og overskride strukturer, indebærer en vending væk fra et socialt blik på affekt. Hemmings advarer derfor mod at læse efter autonome affekter og "affektiv frihed". Hun plæderer for at vendingen mod affekt i højere grad, end hun finder, det er tilfældet hos Sedgwick og Massumi må forstå affekter som indskrevet i det sociale. Hvis vendingen er i tråd med den større tendens til psykologisering af strukturelle og politiske problemstillinger, kan den så samtidig gøres til en modmagt til denne tendens ved at give os redskaber til at analysere følelser og affekter, så de giver mobiliserende indsigter? Som Foucault og mange andre har pointeret, er modmagt aldrig uden for magten og vendingerne mod affekt kan således simultant ses som i tråd med og som modstand mod psykologiserings- og individualiseringstendenser. Mange affektteoretiske analyser undersøger og peger på, hvordan affekter er politiske og sociale. Affektteoretiske analyser kan således, som feministisk forskning i mange årtier har gjort, insistere på at indskrive følelser og affekter i det politiske og det sociale ved bl.a. at undersøge, hvordan affekter bevæger sig mellem kroppe, og derfor ikke bør betragtes som individuelt afgrænsede og inderlige, men derimod 'rørelser', som kan have potentielt mobiliserende effekter. Mange politiske bevægelser har gennem tiderne navngivet sig efter netop dét, der har berørt dem affektivt og bragt dem sammen: fra L'Enrages (de rasende) til L'exaltes (de eksalterede) og fra Los Indignados (de indignerede) til de sørgende lørdags-mødre på Taksim-pladsen i Tyrkiet. På samme vis insisterede den tidlige queerbevægelse på vrede som del af sin bevægelse med slagordet 
"Not gay as in happy, but queer as in fuck you!".

Hvad vendingen mod affekt er og kan, er der ikke ét svar på. Vi taler derfor heller ikke om affektteori i denne indledning, men i stedet om "perspektiver" og om "vending mod affekt". Begrebet 'vending' kan, som Dorthe Staunæs og Mathias Danbolt påpeger det $\mathrm{i}$ en samtale $\mathrm{i}$ dette temanummer, indebære mangt og meget. Begrebet skal nok snarere bruges i flertal, da der er tale om mange forskellige tilgange til affekt. Man kan således vende sig på mange måder - bort fra, hen mod, rundt.

Den mest fremtrxdende brudflade mellem forskellige vendinger mod affekt er de divergerende ontologiske og epistemologiske fortolkninger af affekt, der ofte henviser til hhv. Brian Massumis og Silvan Tomkins' bidrag (se f.eks. Hemmings 2005; Frederiksen \& Petersen 2010). På trods af, at Sedgwick og Massumi til tider indtager en nærmest kanoniseret status i tekster om 'den affektive vending', har vendingen mod affekt og følelser også andre udtryk og historier. I queerteoretiske sammenhænge har vendingen ført til debatter om relationen mellem affekt og race. Sedgwick og Franks artikel om denne relation førte for eksempel til en række kontroverser omkring, hvordan vi skal forstå relationen mellem skam og hvidhed (e.g. Halperin \& Traub 2009; Halberstam 2005; Perez 2005). Indenfor litteraturvidenskab kobles vendingen ofte til analyser, der flytter fokus fra teksten til læserens affektive reception af denne. Analyser som er mindre teorifokuserede, end faget ellers har tradition for. I filosofifaget er det sjældent læsningen, men derimod tekster, der udgør analysernes objekt, og her kan vendingen ses som et return, hvor klassiske filosoffer (bl.a. Spinoza) genlæses og analyseres påny med fokus på deres tanker om følelsesliv. I historiefaget spørges der til, hvorvidt og hvordan følelser har været drivkræfter bag historiske forandringer og de ontologiske diskussioner drejer sig primært om, hvorvidt nutidige teorier og begreber om menneskets kognitive og psykologiske funktioner, samt teorier om affekt, kan forklare historiske forandringer i tidsperioder, der havde andre begreber for og ideer om følelser og affekter, end vi har i dag. ${ }^{2}$ På trods af forskellene på, hvordan affekt undersøges i forskellige fagtraditioner og indenfor forskellige affektteoretiske retninger, kunne en sammenfatning af de analyser, der placeres i den affektive vending være, at de overskrider dikotomier mellem krop/bevidsthed, følelse/fornuft og individ/samfund. For eksempel kan affektteoretiske analyser på tværs af fag vise, hvordan dét, som opfattes som følelsesmæssigt, er fyldt med politik og struktur, og det som opfattes som fri fra følelser, som politik og fornuft, er fyldt med selvsamme. Affektteoretiske perspektiver kan således anvendes til at undersøge, hvordan affekter gøres (og bruges), og hvor visse affekter kan bringe os - og har bragt os - hen. Det er blandt andet sådanne spørgsmål, vi vil udforske i dette temanummer. Hvor sådanne spørgsmål nok kunne være mulige at undersøge uden blik for materialitet, er det sjældent tilfældet i analyser, der placerer sig indenfor den affektive vending. Perspektiverne giver nemlig blik for krops-lige aktioner og reaktioner, som ikke nødvendigvis er sprogliggjorte, og flere af artiklerne i dette temanummer vil således også give eksempler på, at perspektiver, der inddrager affekt, er brugbare til at få blik for sammenvævninger mellem diskurs og materialitet.

Vi håber, at temanummeret kan bidrage til samtaler om, hvorledes interessen for affekt kan udfoldes så dens overskridende potentialer udvikles og ikke bliver fanget ind i frugtløse definitionskampe mellem forskellige positioner. Derfor åbner vi temanummeret med netop en samtale. Christina Hee Pedersen mødtes med to danske forskere, der skriver inde i vendingen: Dorthe Staunæs og Mathias Danbolt, blandt andet for at tale om, hvilke teoretiske forestillinger og tankefigurer vendingen har åbnet for 
dem, og hvilket potentiale de affektive tilgange indeholder for kønsforskningen. I samtalen bevæger vi os også ind på forholdet mellem affektteoretiske perspektiver og poststrukturalisme med et spørgsmål om, hvorvidt de poststrukturalistiske analyser har gjort, hvad de skulle for kønsforskningen, og om generation har betydning for den måde affekt forstås på i dag.

Efter interviewet bringer vi artiklen: "Yes We Can? The Promises of Affect for Queer Scholarship” af queer- og kønsteoretiker Anu Koivunen (bragt første gang i lambda nordica 2010, 3-4). Koivunen argumenterer, ligesom Staunæs og Danbolt, for at vendingen mod affekt skal læses i plural, da den er en paraplybetegnelse, der kan betyde mange ting samtidigt. Artiklen er derfor en god indgang til affektperspektiverne. Koivunen kritiserer dikotomier, der ofte konstrueres i diskussioner af 'den affektive vending', som når vendingen opstilles som en modsætning til en 'anti-social vending' (stærkest repræsenteret af Lee Edelman) eller når Sedgwicks begreber om reparative og paranoide læsninger forstås som læsninger, forskeren frit kan vælge til og fra. I stedet foreslår Koivunen, at begreberne indebærer en beskrivelse af et queert forskersubjekts ontologiske situation og nødvendige pendling mellem en negativ og en positiv hermeneutik.

Samtalen med Danbolt og Staunæs, samt Koivunens artikel, bevæger sig således på et metaplan, der diskuterer vendingerne mod affekt i køns- og queerforskning. Resten af temanummeret har karakter af et affektteoretisk analysepotpourri, forstået således, at bidragene giver eksempler på, hvordan affektteoretiske perspektiver kan bruges til at sætte fokus på affekters politiske potentialer og implikationer på måder, der overskrider opdelingen mellem mikro- og makroplan og til at undersøge affektive relationer mellem forfatter/kunstner, læser/beskuer og værk. Vendingen mod læserens affektive reaktion findes hos både Klara Meijer og Signild Linderoth Christiansen. I begge disse tekster er det forfatterens affektive læsning af og interaktion med teksten, der gøres til genstand for analyse, mens Sanne Fræer Andersen og Helle Bjerg fokuserer på de politiske og normative aspekter af affekter og følelser.

Klara Meijer fører læseren igennem en overraskende og skæv læsning af Inger Christensens eksperimenterende roman fra 1967 Azorno. Hun inddrager i sin Sedgwickske analyse sine egne affektive reaktioner på sin første læsning af romanen, nemlig skam og paranoia. Affekter er individuelle, mener hun, men de er også kollektive, fordi de skabes i sociale og kulturbundne kontekster, og derfor kan belyse og udstille dominerende samfundsstrukturer. Meijer viser, hvorledes romanen forandrer begrebet romantisk kærlighed til en skamfuld og paranoid ide, og belyser, hvordan læser og romanfigurer kommer til at dele både skam og lyst.

Ligeledes med fokus på sin egen affektive reaktion læser Signhild Linderoth Christiansen performanceværket Cry Me a River via Sara Ahmeds fokus på affekters og følelsers performative karakter. Der lægges vægt på forfatterens egen interaktion med værket, der i tråd med Ahmeds teorier beskrives som følelsernes 'manipulerende mulighed og min vanemæssige respons'. Linderoth Christiansen argumenterer for, at Ahmeds normkritiske affektteori kan åbne op for læsninger af performancekunst, der rækker ud over klassiske æstetiske analyser.

Sanne Fræer Andersens artikel er en oversigt over centrale ideer i den affektteori mange feministiske forskere trækker på. Hun viser, hvorledes både Sara Ahmed i The Promise of Happiness og og Lauren Berlant i Cruel Optimism lokaliserer og analyserer de følelsesmæssige strukturer og regulativer som (per)former, reproducerer og sætter rammer for glæde, håb og det gode liv i en tid, hvor magten er smilende. Hun giver konkrete eksempler fra den offentlige debat i Danmark om den stigende individualisering af enhver form for krise og 
viser, at begreberne 'ond optimisme' og 'pligten til glæde' kan være med til at forklare spændingerne i det neoliberale hverdagsliv.

Hvor temanummerets øvrige bidrag trækker på en tradition med Eve K. Sedgwick, Silvan Tomkins og Sara Ahmed som centrale teoretikere, er Helle Bjergs artikel et eksempel på et perspektiv, der læser interaktioner og tilblivelser via Massumis begreber om intensitet og affekt. Bjerg undersøger tilblivelser af hegemonisk(e) maskulinitet(er), hvidhed og sorthed i skolekontekster igennem 3 årtier via en analyse af en række erindringer fra skoleliv. Med erindringerne som omdrejningspunkt viser hun, hvordan maskulinitet, identiteter og subjektiviteter bliver til i mødet mellem kroppe.

Temanummerets bidrag viser, at vendingerne mod affekt har sat aftryk i kønsforskningen, men kan også læses som udtryk for, at undersøgelser af følelser og affekt ikke er en ny søgen, men må forstås som en fort-sættelse af og i kontinuitet med tidligere feministisk forskning. Som når Liljeström og Paasonen for eksempel argumenterer for at interessen for subjektivitet, affekt og forskningsetik har været en central del af femi-nistisk forskning siden 1980'erne (Liljeström \& Paasonen 2010). Vi håber, at I vil læse de fem bidrag som udtryk for at blik for affekt kan afstedkomme muligheder, mobiliseringer og politiske potentialer i kønsforskningen, og at feministiske analyser af og med affekt vil kunne bidrage med noget særligt, når fænomener, der forstås som affektive eller følelsesmæssige, undersøges.

Det kan ikke undgås, at læseren lægger mærke til Ursula Andkær Olesens digte fra digtsamlingen Det 3. årtusindes hjerte (Gyldendal 2012) midt i nummeret. Ursula Andkær Olsens digte emmer af følelser og politik, og vi er glade for, at hun sagde ja til, at vi måtte bringe digtene i denne sammenhæng. Lyrikken forbinder på forunderlig vis tanke, krop og følelser og er ingen luksus, men en vital nødvendighed for at kunne leve, som Audre Lorde formulerede det $i$ et af sine kendte essays:

Poetry is the way we help give name to the nameless so it can be thought. The farthest horizons of our hopes and fears are cobbled by our poems, carved from the rock experiences of our daily lives (Lorde 1984: 37).

\section{Noter}

1. Fx var temaet for den danske årskonference for kønsforskning i 2012: "Tro, håb og kærlighed". 2. I historikeren Thomas Dixons værk From Passions to Emotions. The Creation of a Secular Psychological Category (2003) er argumentet, at den nutidige kategori 'emotions' må afvises, når vi skal forstå forandringer i førmoderne tid, hvor det vi i dag forstår under denne kategori, var opdelt i mange forskellige begreber som fx 'affekter', 'passioner', 'drifter' og 'begærer'.

\section{LITTERATUR}

- Al-Samman, Hanadi \& Tarek El-Ariss (2013): Queer Affects: Introduction, i: International Journal of Middle East Studies 45 (02): 205-209.

- Andkær Olesens Ursula (2012): Det 3. artusindes hjerte. Gyldendal, København.

- Blackman, Lisa \& Mike Featherstone (2010): Revisioning Body \& Society, i: Body \& Society 16 (1) (March 1): 1-5.

. Clough, P.T. \& J. Halley (2007): The Affective

Turn: Theorizing the Social. Duke University Press, Durham.

- De Vos, J. (2012): Psychologisation in Times of Globalisation. Concepts for Critical Psychology. Taylor \& Francis, London

- Dixon, Thomas (2003): From Passions to Emotions. The Creation of a Secular Psychological Category. Cambridge University Press, Cambridge. - Frederiksen, M. Bissenbakker \& Michael Nebeling Petersen (2012): I Affekt: Skam, Frygt Og Jubel Som Analysestrategi. Lokaliseret (d.

5/11/2013) på: http://koensforskning.ku.dk/ nyeudgivelser/varia/

. Fritsch, Jonas \& Thomas Markussen (2012): Exploring Affect in Interaction Design, Interaction- 
based Art and Digital Art, i: The Fibreculture Journal 2012 (21): 1-9.

. Gregg, M.,\& G.J. Seigworth (2010): The Affect Theory Reader. Duke University Press, Durham.

- Halberstam, Judith (2005): Shame and White Gay Masculinity, i: Social Text 23 (3-4 84-85): 219-233.

- Halperin, David M. \& Valerie Traub (2009): Gay Shame. University of Chicago Press, Chicago.

- Hemmings, Clare (2005): Invoking Affect: Cultural Theory and the Ontological Turn, i: Cultural Studies 19 (5): 548-567.

- La Caze, Marguerite \& Henry Martin Lloyd (2011): Editors' Introduction: Philosophy and Affective Turn', i: Parrhesia 13: 1-13.

- Liljeström, Marianne \& Susanna Paasonen (2010): Working with Affect in Feminist Readings:

Disturbing Differences. Routledge, London.
- Lorde, Audre (1984): Sister Outsider. Essays and speeches. Crossing Press, Berkley.

- Massumi, Brian (1995): The Autonomy of Affect, i: Cultural Critique (31) (October): 83-109. University of Minnesota Press, Minnesota. - Pedwell, Carolyn \& Anne Whitehead (2012): Affecting Feminism: Questions of Feeling in Feminist Theory, i: Feminist Theory 13 (2) (August 1): 115-129.

- Perez, Hiram (2005): You Can Have My Brown Body and Eat It, Too!, i: Social Text 84: 171.

. Sedgwick, Eve Kosofsky \& Adam Frank (1995): Shame in the Cybernetic Fold: Reading Silvan Tomkins, i: Critical Inquiry 21 (2) (January 1): 496-522.

- White, Melissa Autumn (2008): Critical Compulsions: On the Affective Turn, i: TOPIA: Canadian Journal of Cultural Studies (19): 181-188. 